\title{
Ownership, Managerial Entrenchment, and Corporate Performance
}

Praveen Kumar \& Alessandro Zattonni

More than eighty years after the seminal work of Berle \& Means (1932), the corporate governance (CG) literature is continuing to advance our understanding of the various implications of the separation of ownership and control in public firms. In particular, at the level of the firm, the literature has examined both theoretically and empirically the internal and external governance mechanisms that monitor and moderate managerial influence and power.

Specifically, there is an extensive literature on internal mechanisms, such as an effective board of directors (Adams et al, 2010; Pugliese et al., 2009; Van Den Berghe \& Levrau, 2004; ), and external mechanisms, such as monitoring by large shareholders and institutional investors (Gillan \& Starks, 2000; McLaren, 2004).

Of course, these governance mechanisms do not eliminate the possibility that managers get entrenched because it becomes costly and difficult for boards and shareholders to remove them. The literature advances several reasons for managerial entrenchment. For example, organizational theorists argue that tenure and CEO's internal power are positively related (e.g., Finkelstein \& Hambrick, 1989), making it difficult for boards to wrest control from long-serving CEOs. Furthermore, shareholder actions, such as proxy motions against management, are costly for individual shareholders to undertake (Fluck, 1999) and sometimes not even legally binding. Similarly, takeover threats by external blockholders are financially costly, and often not credible threats for management of large companies (Cyert et al., 2002). In addition, managers may proactively choose actions that facilitate entrenchment (Shleifer \& Vishny, 1989).

Our knowledge of the consequences of such entrenchment and the moderating role of ownership structure is still limited, and thus is a fertile area for research by CG scholars. There is evidence that entrenchment and weak governance have negative consequences for operational and financial performance (Core et. al., 1999). In addition, the recent literature has shown that entrenched managers are more likely to choose investment and financial policies that are not in the best interests of firms' various stakeholders (Hu \& Kumar, 2004; Kang et al., 2006; Kumar \& Rabinovitch, 2013). However, many important questions remain unanswered in the literature. In particular, we need research on the impact of ownership structures and managerial entrenchment on other important areas of firm performance, such as innovation and financial transparency. 
This type of research should build on findings, for example, that ownership types matter for broader areas of performance, such as corporate social responsibility (Dam \& Scholtens, 2012). More broadly, while entrenchment and its interaction with ownership structure are typically analyzed through the lens of agency theory, how can we broaden the conceptual framework to allow insights from other theoretical frameworks, such as institutional and resource-based theories?

In this issue, we have three papers that examine these issues and generate significant new results and insights. In the first paper, Lodh et al. examine the incentive effects of family ownership for innovation productivity, an issue that has thus far received limited attention in the literature on family ownership. But it is well known that growth opportunities generated by innovations and development of new economic opportunities are central to the evolution of industries and economic growth (Schumpeter, 1942; Romer, 1990). Moreover, family ownership is probably the most widely prevalent form of business globally. Hence, the findings of this study are important and timely, especially for emerging economies. On the one hand, the impact of innovations is especially significant for the economic growth of emerging economies. On the other hand, the relatively undeveloped institutional structures in such economies constrain innovation activity. In these countries, family ownership and affiliation with family-owned business groups can potentially offset the deficiencies of the institutional structure (Zattoni et al., 2009). From a theoretical perspective, the emerging market setting provides an interesting tension between the predictions of agency and institutional theories regarding innovation. Using data on publicly listed firms in India during 2001-2008, Lodh et al. find that family ownership has a positive influence on innovation productivity, even after controlling for endogeneity in ownership structure. They also find that business group affiliation amplifies the positive relation of family ownership to innovation.

The Lodh et al. study nevertheless indicates that interfacing with stock markets through public listing and using professional managers may further increase innovation productivity of family firms, which is consistent with other studies (Choi et al., 2012). Indeed, as we noted above, the literature considers the role of large external shareholders, in particular institutional investors and the problems that constrain their effectiveness in monitoring management (Webb et al., 2003). However, there is considerable heterogeneity in such investors, owning to differences in objectives, investment horizons, and investment styles. The literature has thus far paid 
relatively little attention to this heterogeneity. In particular, there is little information on the types of institutional investors that appear to be more effective in constraining management. The paper by Wang advances significantly our understanding on this important issue. Using data on UK firms from 1997-2010, Wang analyzes the question: What type of institutional investors constrains strategic earnings management (through accruals management) by corporate insiders? Such types of accounting manipulation make the performance of the firm more opaque to outside investors (García-Meca \& Sánchez-Ballesta, 2009). The results show that the level of holdings, the investment strategies adopted by the institutional investor, and the duration of the investment holdings are all implicated in the effectiveness of managerial monitoring. Intuitively, one expects that there must be a minimum level of holdings, activist investment style, and reasonable investment duration for institutional investors to have a significant impact in constraining management's attempts at income-inflating accruals management. Wang's study confirms this intuition and generates additional results of interest. It will contribute in bringing much needed clarity in an important CG area.

Finally, the study by Lin et al. examines the effects of managerial entrenchment in resisting changes in national level regulatory changes that are made to improve governance performance at the firm level. This issue is important for the CG literature because there is substantial interest in improving our understanding of the links between national- and firm-level governance variables (Bamberger, 2008; Cuomo et al., 2013; Kumar \& Zattoni, 2013; Zattoni \& Judge, 2012). Specifically, the Sarbanes-Oxley Act, which was passed in the U.S. in 2002 in response to many corporate governance scandals, requires management to disclose the quality of their internal accounting and financial controls. Lin et al. study whether CEO characteristics are systematically related to firms' exploitation of weak internal controls to serve the self-interest of management, such as inflated earnings reports. Using archival data on a large sample of U.S. firms, they find that entrenched CEOs are more likely to exploit weak internal controls, while older CEOs who have smaller remaining career horizons to benefit from such manipulation, are less likely to do so. This study uses a natural experiment, namely, an exogenous change in governance-related regulation to clarify the moderating role of management characteristics on the effects of national governance variables on firm-level governance performance. This type of approach may be useful in clarifying the role of other firm-level characteristics, such as variables 
related to the board and other stakeholders, in moderating the effects of national governance factors on corporate governance mechanisms.

\section{References}

Adams, R. B., Hermalin, B. E., \& Weisbach, M. S. 2010. The role of boards of directors in corporate governance: A conceptual framework and survey. Journal of Economic Literature, 48: $58-107$.

Bamberger, P. 2008. Beyond contextualization: Using context theories to narrow the micromacro gap in management research. Academy of Management Journal, 51: 839-846.

Berle, A., \& G. Means, 1932. The Modern corporation and private property. New York: Macmillan.

Choi, S. B., Park, B. I., \& Hong, P. 2012. Does ownership structure matter for firm technological innovation performance? The case of Korean firms. Corporate Governance: An International Review, 20: 267-288.

Core, J., Holthausen, R., \& Larcker, R. 1999. Corporate governance, chief executive officer compensation, and firm performance. Journal of Financial Economics, 51:371-406.

Cuomo, F., Zattoni, A., \& Valentini, G., 2013. The effects of legal reforms on the ownership structure of listed companies. Industrial and Corporate Change, 22(2): 427-458.

Cyert, R.M., P. Kumar, \& S-K.Kang. 2002. Corporate governance, takeovers, and topmanagement compensation: theory and evidence. Management Science, 48: 453-469.

Dam, L. \& Scholtens, B. 2012. Does ownership type matter for corporate social responsibility? Corporate Governance: An International Review, 20: 233-252.

Finkelstein, S., \& D. Hambrick. 1989. Chief executive compensation: A study of the intersection of markets and political processes. Strategic Management Journal 10: 121-134.

Fluck, Z. 1999. The dynamics of the management-shareholder conflict. Review of Financial Studies, 12: 379-404.

García-Meca, E. \& Sánchez-Ballesta, J. P. 2009. Corporate governance and earnings management: A meta-analysis. Corporate Governance: An International Review, 17: 594-610.

Gillan, S., \& Starks, L. 2000. Corporate governance proposals and shareholder activism: The role of institutional investors. Journal of Financial Economics 57: 275--305. 
Hu, A., \& Kumar, P. 2002. Managerial entrenchment and payout policy. Journal of Financial and Quantitative Analysis, 39: 759-790.

Kang, S-K, Kumar, P., \& Lee, H. 2006. Agency Costs and corporate investment: the role of executive compensation and corporate governance. Journal of Business, 79: 1127-1148.

Kumar, P., \& Rabinovitch, R. 2013. CEO entrenchment and corporate hedging: evidence from the oil and gas industry. Journal of Financial and Quantitative Analysis, 48: 88V7-917.

Kumar, P., \& Zattoni, A. 2013. How much do country-level or firm-level variables matter in corporate governance studies? Corporate Governance: An International Review, 21: 199-200.

McLaren, D. 2004. Global stakeholders, corporate accountability and investor engagement. Corporate Governance: An InternationalReview, 12: 191-201.

Pugliese, A., Bezemer, P., Zattoni, A., Huse, M., Van Der Bosch, F., Volberda, H. 2009. Boards of Directors' Contribution to Corporate Strategy: A Literature Review and Research Agenda. Corporate Governance: An international Review, 17: 292-306.

Romer, P., 1990. Endogenous technological change. Journal of Political Economy 98: 71102.

Schumpeter, J., 1942. Capitalism, socialism, and democracy. New York: Harper and Row.

Shleifer, A., \& R. Vishny. 1989. Management entrenchment: the case of manager-specific investments. Journal of Financial Economics, 25: 123-139.

Van Den Berghe, L., \& A. Levrau. 2004. Evaluating boards of directors: what constitutes a good corporate board? Corporate Governance: An International Review, 12:461-78.

Webb, R., Beck, M., \& McKinnon, R. 2003. Problems and limitations of institutional investor participation in corporate governance. Corporate Governance: An International Review, 11: $65-73$.

Zattoni, A., Pedersen, T., and Kumar, V. 2009. The performance of group-affiliated firms during institutional transition: a longitudinal study of Indian firms. Corporate Governance: An international Review, 17: 510-523.

Zattoni, A., \& Judge, W. 2012. Corporate governance and initial public offerings: An international perspective. Cambridge: Cambridge University Press.

Zattoni, A., Gnan, L., \& Huse, M. 2013. Does family involvement influence firm performance? Exploring the mediating effects of board processes and tasks. Journal of Management, forthcoming. 